\title{
Má opravdu „každý““ právo na život?
}

\section{Has Really "Everyone" Right to Life?}

\author{
Jakub Valc*
}

\begin{abstract}
Abstrakt
Cílem daného clánku bude kriticky z̧hodnotit soüasnou koncepci ústavnëprávni ochrany lidského života $v$ Ceské republice, a to v počátcich jeho prïrozeného vývoje. Za tímto účelem bude nejprve pomoci filozoficko-právni analýzy modernich embryologických poznatki stanoven morálni a právni status nenarozenébo ditète. Takto zjištèné poznatky budou následnè konfrontovány se soǔasnou českou právni úpravou dané problematiky. V této souvislosti budou rovnèž uvedeny úvaby de lege ferenda, dle kterých by mèla prìslušná

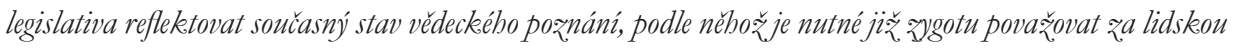
osobu majici právo na život a lidskou distojnost.
\end{abstract}

\section{Klíčová slova}

Lidský život; právo na život; lidská dìstojnost; zygota; lidská osoba.

\begin{abstract}
The aim of the article will be to critically evaluate the current concept of the constitutional protection of buman life in the Czech Republic, in the infancy of its natural development. For this purpose will be by using philosophical and legal analysis of modern embryological knowledge formulate moral and legal status of unborn child. These findings then will be confronted with the current czech legislation of the issue. In this context will be also define consideration de lege ferenda, that the relevant legislation should respect the current findings of scientific knowledge according to which it is necessary to consider that already the aygote is a buman person, who has the right to life and human dignity.
\end{abstract}

\section{Keywords}

Human Life; Right to Life; Human Dignity; Zygote; Human Person.

\section{Úvod}

Vlivem tragických událostí druhé světové války byly státy napříč mezinárodním společenstvím nuceny vzájemně spolupracovat za účelem vytvoření efektivního systému lidskoprávní ochrany. Výsledkem bylo založení mnoha mezinárodních organizací a přijetí významných lidskoprávních dokumentů. ${ }^{1}$ Za první ucelený katalog lidských práv na mezinárodní úrovni pak můžeme považovat zejména Všeobecnou deklaraci lidských

* Mgr. Jakub Valc, doktorand, Katedra právní teorie, Právnická fakulta, Masarykova univerzita, Brno / Ph.D. student, Department of Legal Theory, Masaryk University, Brno, Czech Republic / E-mail: 380851@mail.muni.cz

1 MACMILLAN, Margaret. Rebuilding the world after the second world war. Theguardien [online]. Posted on 11. September 2009 [cit. 18. 5. 2016]. Dostupné z: http://www.theguardian.com/world/2009/ sep/11/second-world-war-rebuilding 
práv z roku 1948 (dále jen „Deklarace“). Přestože není právně závazná, stala se východiskem pro veškerou následnou legislativu v dané oblasti. ${ }^{2} \mathrm{~V}$ kontextu našeho príspěvku je nutné konkrétně vymezit především čl. 3 Deklarace, který stanoví, že: „Každý má právo na život, svobodu a osobni bezpečnost" 3 Toto na první pohled zcela srozumitelné ustanovení však již delší dobu vyvolává $\mathrm{v}$ rámci odborného diskurzu mnoho interpretačních kontroverzí, nebot’ výslovně neuvádí, zda lze pod pojem „každý“ subsumovat také nenarozené dítě v jednotlivých stádiích vývoje. ${ }^{4} \mathrm{~V}$ ústavněprávní rovině pak některé evropské státy, včetně České republiky, výslovně vyčleňují z práva na život ochranu nenarozeného dítěte, čímž umožňují přijetí právní úpravy, která legalizuje destruktivní zásahy do jeho přirozeného vývoje. ${ }^{5}$

Cílem tohoto článku tak bude poukázat na skutečnost, že uvedeným př́istupem dochází také ze strany českého zákonodárce $\mathrm{k}$ diskriminaci nenarozeného dítěte. Je totiž nutné pracovat s moderními embryologickými poznatky o počátku a vývoji lidského života v prenatálním období. Jejich filozoficko-právní (kritickou) analýzou poté můžeme dospět k závěru, že již zygota či embryo nejsou pouhou buněčnou masou nebo shlukem buněk, ale naopak lidskou osobou, která má právo na život a lidská důstojnost.

\section{Status osoby: předpoklad či důsledek přirozeného vývoje?}

Pro účely našeho výkladu by bylo vhodné, aby si každý nejprve formulovat výchozí otázku: „Kdy jsem se stal lidskou osobou?“ Lze již předem říci, že jakkoliv si na danou otázku kvalifikovaně odpovíme, nikdy nebude naše odpověd’ zcela empiricky ověřitelná. Můžeme samozřejmě primárně vycházet z dnes již vědecky potvrzených faktů, že následkem realizace biologického procesu oplození vzniká originální a geneticky jedinečný lidský organismus - zygota, která následně prochází předem stanoveným vývojem až do svého narození. ${ }^{6}$ Otázky týkající se morálního statusu nenarozeného dítěte jsou však svoji povahou filozofické či etické, přičemž doslova polarizují odbornou veřejnost na dva hlavní názorové proudy. Jedním z nich je ontologický personalismus, který po-

2 ALFREDSSON, Gudmundur, EIDE, Asbjørn. The Universal Declaration of Human Rights: A Common Standard of Achievement. The Hague: Kluwer Law International, 1999, s. 3. ISBN 90-411-1168-9.

3 Všeobecná deklarace lidských práv. Informační centrum OSN v Praže [online]. UNIC Praha [cit. 18. 5. 2016]. Dostupné z: http://www.osn.cz/wp-content/uploads/2015/12/UDHR_2015_11x11_CZ2.pdf

4 Stejný „,interpretační problém“ můžeme rovněž pozorovat u následně přijatých závazných lidskoprávních dokumentů, a to ve smyslu čl. 2 odst. 1 Úmluvy o ochraně lidských práv a základních svobod, která má v českém právním řádu podobu sdělení federálního ministerstva zahraničních věcí č. 209/1992 Sb. o sjednání Úmluvy o ochraně lidských práv a základních svobod a Protokolů na tuto Úmluvu navazujících. Dalším konkrétním př́kladem je poté čl. 6 odst. 1 Mezinárodního paktu o občanských a politických právech, resp. vyhlášky ministra zahraničních věcí č. 120/1976 Sb., o Mezinárodním paktu o občanských a politických právech a Mezinárodním paktu o hospodářských, sociálních a kulturních právech.

5 Typickým př́kladem je čl. 6 odst. 1 věty druhé ústavního zákona č. 2/1993 Sb., Listina základních práv a svobod, ve znění pozdějších předpisů (dále jen „Listina“): „Lidský život je hoden ochrany jižpred naroz̧enim“.

6 PASCAL, Ide. Je zygota lidskou osobou? Praha: Triton, 2012, s. 147-150. ISBN 978-80-7387-526-8. 
važuje lidský život za nedotknutelnou hodnotu ve všech stádiích vývoje, tedy od početí až do klinické smrti. Za jeho pomyslnou opozici pak lze označit empirický funkcionalismus, který je myšlenkově založen na interpretačním rozlišování pojmů bytost a osoba. Bytostí je v tomto pojetí každý člen lidského druhu, ale osobou jen takový, který disponuje určitými schopnostmi. ${ }^{8}$

Odborníci na bioetiku a filozofové Tom L. Beauchamp a James Franklin Childress v této souvislosti uvádějí nezbytnost přítomnosti kognitivní kapacity, morálního rozvažování, schopnost vnímání a začlenění do sociálního prostředí. Za osobu tak lze v tomto kontextu považovat pouze bytost, která je schopna autonomního jednání a projevu vưle navenek. Současně však u ní musí být dány předpoklady pro morální hodnocení, tedy schopnost morálního soudu. Klíčovým je taktéž požadavek na určitý stupeň nervové aktivity, umožňující vnímání libosti či nelibosti (typicky bolesti). ${ }^{9}$ Problém této koncepce však spočívá v její selektivnosti. Uvedené požadavky totiž nemohou objektivně splnit ani novorozenci nebo osoby v bezvědomí či stižené duševní poruchou apod. ${ }^{10}$ Degradace počatého dítěte na pouhého člověka v potenci či agresora ohrožujícího matčinu existenci ovšem nereflektuje také biologickou skutečnost, že vývoj embrya je autonomním a prrirozeným procesem, který je v podstatě jedním z atributů lidské přirozenosti. Každého člověka je tak nutné respektovat jako lidskou osobu ve všech fázích jeho vývoje, tedy bez jakékoliv diskriminace. ${ }^{11}$

\section{Lidské embryo a jeho právní status}

Vlivem postupné liberalizace společnosti došlo napříč moderními demokraciemi k legalizaci řady právních institutů, které představují významné problémy z hlediska bioetiky.

7 Z teologického hlediska můžeme hovořit o teorii bezprostřední animace či oduševnění, která je zakotvena rovněž v dokumentu katolické církve Donum Vitae, který reflektuje její jednotný postoj ve vztahu k nedotknutelnosti lidského života již od okamžiku početí. Srov. JANS, Jan. The Moral Status of the Human Embryo according to Donum Vitae. In: Viz HOOSE, Bernard, CLAGUE, Julie, MANNION, Gerard (eds.). Moral theology for the twenty-first century. New York: t \& t clark, 2008, s. 97. ISBN 978-0-567-62143-6.

8 SULLIVAN, Denis M. The conception view of Personhood: A Review. Ethics and Medicine [online]. 2003, vol. 19, s. 17-18 [cit. 22. 5. 2016]. Dostupné z: https://www.cedarville.edu/personal/sullivan/bio4710/ papers/conception.pdf

9 HEŘMANOVÁ, Jana a kol. Etika v ošetrovatelské praxi. Praha: Grada, 2012, s. 24-30. ISBN 978-80-247-8336-9.

10 Stejnou komplikaci ostatně představuje také alternativa k uvedeným př́istupům v podobě tzv. gradualismu, dle kterého nenarozené dítě postupně dospívá do svého úplného morálního statusu. Jeho zastánci totiž nemohou dosáhnout konsensu v otázce, kdy tento rozhodný okamžik nastává. Viz LAJKEP, Tomáš. Lidské embryo - kdo, nebo co? Zdravotnické noviny [online]. Publikováno dne 7.3. 2003 [cit. 24. 5. 2016]. Dostupné z: http://snoubenci.ascczech.cz/?a=1\&b=97\&id=1654\&SSID=49102c0c5bddc4e47d5f1de9a417093b

11 Nenarozené dítě je navíc morálně nevinné, nebot' není během prenatálního období schopno ovlivňovat průběh či důsledky svého vývoje. Viz HOLÓWKA, Jacek. Abortion. In: BYRD, Sharon, B., HRUSCHKA, Joachim, JOERDEM, Jan, C. (eds.). Jabrbuch für Recht und Ethik. / Annual Review of Law and Ethics. Berlin: Duncker\&Humblot, 2012, s. 286-289. ISBN 978-3-428-13960-6. 
Za přední z nich můžeme považovat realizaci umělých přerušení těhotenství či výzkumů na lidských embryích. V obou prrípadech se jedná o intencionální zásahy do podstaty a vývoje lidského života, jejichž právní regulace však není v jednotlivých evropských státech jednotná. ${ }^{12}$ To je zajisté podmíněno různými postoji v rámci jednotlivých společností, což souvisí zejména s odlišným historicko-kulturním vývojem. Státy se silnou katolickou tradicí, jako je Polsko či Irsko, tak přirozeně disponují restriktivní právní úpravou v daných oblastech. ${ }^{13}$ Můžeme však konstatovat, že se v evropském právním prostoru jedná spíše o výjimky, nebot’ většina států, včetně České republiky, považuje interrupce za legitimní nástroj k realizaci práva ženy rozhodovat o svém těhotenství. Daný právní režim však způsobuje, že jsou tyto lékařské postupy primárně využívány k řešení sociálních, ekonomických či jiných (ne zdravotních) problémů. ${ }^{14}$

Jiné argumenty jsou však uplatňovány ve vztahu k ospravedlnění výzkumů na lidských embryích. Jejich hlavním cílem je totiž využití získaných poznatků pro účely rozvoje v oblasti terapeutického klonování, které by v budoucnu mohlo zajistit spolehlivou léčbu závažných onemocnění. S tím ovšem souvisí nejen hrozba reprodukčního klonování, ale zejména destrukce použitých embryí. ${ }^{15} \mathrm{Z}$ těchto důvodů jsou tyto výzkumy pravidelně legislativně umožněny jen na embryích v počátku vývoje (např̀. do 14. dne vývoje ve Velké Británii), popř. jen na nadbytečných embryích po oplodnění in vitro neboli ve zkumavce (např. Španělsko). Jsou však i některé státy, které embryo-destruktivní výzkumy zcela zakazují. ${ }^{16}$

Zaměříme-li se konkrétně na právní prostředí České republiky, je problematika interrupcí zakotvena vedle obecné právní úpravy zdravotních služeb zejména v zákoně č. 66/1986 Sb., o umělém přerušení těhotenství, popř̀. v prŕíslušném prováděcím právním předpisu. Jak již bylo naznačeno, svojí povahou patří mezi nejliberálnější v Evropě. Dle př́sluš-

12 Nejednotnost legislativy v dané právní oblasti je dána zejména normotvornou pasivitou ze strany Evropské unie, ale také nejasnou interpretací Evropského soudu pro lidská práva, který se doposud výslovně nevyjádřil k otázce počátku lidského života a jeho právní ochrany (např. rozhodnutí Evropského soudu pro lidská práva ze dne 8. 7. 2004, č. 53924/00, ve věci Vo vs. Francie nebo rozhodnutí Evropského soudu pro lidská práva ze dne 10. 4. 2007, č. 6339/05, ve věci Evansová vs. Spojené královstvî). Regulaci tak ponechal na uvážení jednotlivých smluvních států Rady Evropy.

13 Irsko můžeme v tomto kontextu označit za evropskou zemi s nejvíce restriktivní právní úpravou interrupcí v Evropě. Zlomovým okamžikem však bylo přijetí rozhodnutí Nejvyššího soudu Irska ze dne 5. 5. 1992, [1992] ILRM 401, [1992] 1 IR 1, ve věci Attorney General vs. X. and Others, které označilo interrupci za legální nástroj v případě ohrožení života matky. I přes tuto skutečnost však došlo k zásadnějším legislativním změnám ve smyslu daného rozhodnutí až v roce 2013. Viz Irsko povolilo interrupce. Matce však musí jít o život. Tyden.cz [online]. 2016 [cit. 24. 5. 2016]. Dostupné z: http://www.tyden.cz/ rubriky/zahranici/evropa/irsko-povolilo-interrupce-matce-vsak-musi-jit-o-zivot_276293.html

14 Potraty 2013. Ústav żdravotnických informaci a statistiky ČR [online]. 2010-2016, s. 12 [cit. 24. 5. 2016]. Dostupné z: http://www.uzis.cz/publikace/potraty-2013

15 Embryonic stem cell research: an ethical dilemma. Euro stem cell [online]. Last updated 5 November 2015 [cit. 24. 5. 2016]. Dostupné z: http://www.eurostemcell.org/factsheet/embyronic-stem-cell-research-ethical-dilemma

16 Typicky se jedná opět o země se silnou katolickou tradicí, jakou je již zmiňované Irsko. Viz KŘÍŽ, Jakub. Embryo a právo na život. Distance [online]. 2009, č. 3 [cit. 24. 5. 2016]. Dostupné z: http://www.distance. cz/rocnik-2009/3-cislo/embryo-a-pravo-na-zivot 
ných ustanovení totiž může matka až do konce 12. týdne těhotenství rozhodnout o jeho přerušení, aniž by musely být dány zdravotní či jiné zákonné důvody (vyjma kontraindikacî). ${ }^{17} \mathrm{~V}$ ostatních př́padech může být interrupce provedena pouze v zákonem stanovených př́padech, a to ze zdravotních důvodů na straně matky či plodu, popř. z důvodu vývojových nebo genetických vad plodu. ${ }^{18}$ Podobná situace panuje také v oblasti právní regulace embryo-destruktivních výzkumů, a to v režimu zákona č. 227/2006 Sb., o výzkumu na lidských embryonálních kmenových buňkách a o souvisejících činnostech a o změně některých souvisejících zákonů (dále jen ,zákon o výzkumu“). ${ }^{19}$ Ten totiž umožňuje provádět dané výzkumy na embryích, která byla dovezena nebo získána jako nadbytečná od centra asistované reprodukce, pokud nejsou starší více jak sedm dní. $\mathrm{V}$ důsledku se však jedná o způsob selektivní ochrany, která embrya na nižším stupni vývoje degraduje na pouhý biologický či pokusný materiál.

Výše citované normativní právní akty zajisté musí být v souladu s ústavním pořádkem České republiky, jehož součástí je dle čl. 3 ústavního zákona č. 1/1993 Sb., Ústava České republiky, ve znění pozdějších předpisů, také již citovaná Listina. Její hodnotový základ spočívá $\mathrm{v}$ uznání neporušitelnosti přirozených práv člověka a navazování na obecné hodnoty lidství a demokracie, což je konkretizováno také požadavkem na rovnost všech lidí v důstojnosti a právech. ${ }^{20}$ Ve vztahu $\mathrm{k}$ námi řešenému problému je však stěžejní zejména čl. 6 odst. 1 Listiny: „Každý má právo na život. Lidský život je hoden ochrany již pred naroženim. "Jeho prostřednictvím totiž zákonodárce poskytuje ochranu lidskému životu, což je výchozí hodnota každé demokratické právní společnosti, nebot’ v důsledku podmiňuje garanci a ochranu ostatních lidských práv a svobod. ${ }^{21}$

Na základě dikce výše citovaného článku Listiny můžeme tedy konstatovat, že zákonodárce v něm výslovně, byt' poměrně abstraktně, rozlišuje mezi pojetím ochrany lidského života $v$ době před a po narození. Při použití argumentu ad absurdum tak dochází k situaci, kdy tentýž lidský jedinec disponuje odlišným právním statusem ve velmi krátkém časovém rozmezí, přestože realizací porodu fakticky dochází pouze ke změně jeho

$17 \int 4$ zákona o umělém přerušení těhotenství.

18 STOLÍNOVÁ, Jitka. Právní aspekty antikoncepce, sterilizace a interrupce. Moderní babictví [online]. 2004, č. 4, s. 4-6 [cit. 24. 5. 2016]. Dostupné z: http:/ / www.levret.cz/publikace/casopisy/mb/2004-4/?pdf=137

19 Výzkumem na lidských embryonálních kmenových buňkách se poté dle dikce $\int 2$ písm. a) zákona o výzkumu rozumí „systematická tviorǔ činnost konaná za účelem získání nových znalostí nebo jejïch využití provádèná na liniích lidskeých embryonálních kemenových bunèke. "

20 Čl. 1 Listiny.

21 Také komentářová literatura však označuje tuto zákonodárcem použitou formulaci za normativně neurčitou. Z jejího znění totiž není stejně jako v případě uvedených lidskoprávních dokumentů patrné, jaký standard právní ochrany je nenarozenému dítěti de iure přiznáván. Srov. WÁGNEROVÁ, Eliška a kol. Listina zákeladních práv a svobod. Komentár. Praha: Wolters Kluwer ČR, 2012, s. 156. ISBN 978-80-7357-219-0. 
okolního prostředí. ${ }^{22} \mathrm{~K}$ tomu dodejme, že čl. 6 odst. 1 věty první Mezinárodního paktu o politických a občanských právech stanoví, že: „Každá lidská bytost má právo na život.". Přestože s ohledem na okolnosti přijetí daného ustanovení nebylo záměrem chránit lidský život již od početí, je zde výslovně poskytována právní ochrana každému lidskému bytí. Je však poté přinejmenším paradoxní, že samotní zastánci empirického funkcionalismu považují ( $\mathrm{z}$ hlediska interpretace) za lidskou bytost také nenarozené dítě již ve stádiu zygoty. ${ }^{23}$ Stejnou interpretační nepřesnost pak můžeme pozorovat také $\mathrm{v}$ případě čl. 2 Úmluvy o lidských právech a biomedicíně: „Zájmy a blabo lidské bytosti jsou nadřazeny zájmuim spolećnosti nebo védy. "V tomto kontextu bychom se totiž mohli dotazovat, zda lze dané ustanovení považovat za uskutečnitelné za situace, kdy zákonodárce umožňuje na úkor některých lidských bytostí provádět vědecké výzkumy vedoucí k jejich destrukci.

\section{Je právní ochrana nenarozeného dítěte pouhou ústavní hodnotou?}

Otázka právního statusu nenarozeného dítěte nebyla doposud v rámci českého ústavního soudnictví autoritativně posouzena. V tomto ohledu však můžeme analogicky vycházet z přezkumu slovenské interrupční legislativy, která je také v ústavněprávní rovině prakticky identická s českou právní úpravou. ${ }^{24}$ Ústavní soud Slovenské republiky se k dané věci vyjádřil ve svém nálezu ze dne 4. 12. 2007, sp. zn. PL. ÚS 12/01. Objektem jeho rozhodování bylo stanovení právního statusu nenarozeného dítěte, nebot' byla v tomto kontextu napadána možnost ženy rozhodovat o ukončení svého těhotenství až do konce 12. týdne jeho trvání. Příslušný soud dospěl k právnímu závěru, že napadaná interrupční legislativa není rozporuplná s ústavněprávní ochranou lidského života, přičemž z dikce čl. 15 odst. 1 Ústavy SR vyplývá úmysl zákonodárce rozlišovat mezi právem na život a ochranou nenarozeného dítěte.

Dále výkladově dovodil, že právo na život je osobním a subjektivním nárokem, kdežto ochrana nenarozeného dítěte jen ústavní hodnotou. Není pak v souladu s postulátem rovnosti lidí v důstojnosti a právech členit právo na život na dílčí kategorie, obsahující rozdílnou intenzitu ochrany. V př́padě interrupcí se poté nejedná o kolizi dvou základních práv, ale práva ženy na soukromí a ústavní hodnoty v podobě ochrany nenarozeného dítěte. Za ústavně konformní Ústavní soud Slovenské republiky označil také dvanáctitýdenní lhůtu k umělému přerušení těhotenství, nebot’ je v souladu s převláda-

22 Při interpretaci čl. 6 Listiny musíme totiž zohlednit také existenci příslušné zákonné právní úpravy, která umožňuje intencionální zásahy do podstaty a vývoje nenarozeného lidského života. To samo o sobě svědčí o jasné tendenci zákonodárce poskytovat nenarozenému dítěti odlišný standard právní ochrany.

23 Připomeňme totiž, že empirický funkcionalismus zásadně zpochybňuje morální status zygoty či embrya, nicméně nepopírá, že se jedná o lidský organismus, resp. lidské bytí.

24 Dikce čl. 15 odst. 1 ústavního zákona č. 460/1992 Zb., Ústava Slovenskej republiky (dále jen „Ústava SR“) zní: „Každý má právo na život. L’udský život je hodný ochrany užpred narodením." 
jící evropskou praxí. Jejím souladem se současným stavem vědeckého poznání se však nezabýval. ${ }^{25}$

Dle našeho názoru je naopak nutné stanovovat právní status nenarozeného dítěte při současné reflexi embryologických poznatků, které by měly být v tomto smyslu určitým argumentačním východiskem. Daným rozhodnutím totiž byly lidské bytosti výkladově kategorizovány na dvě pomyslné skupiny, kterým je poskytován různý standard právní ochrany. V tomto postupu pak spatřjeme znaky diskriminačního jednání, které je v rozporu s principy moderního právního státu a demokracie.

\section{Právní status nenarozeného dítěte $\mathrm{v}$ úvahách de lege ferenda}

Nelze samozřejmě zpochybnit, že mezi nenarozeným dítětem a jeho matkou vzniká zcela ojedinělý biologický vztah. Jejich koexistenci totiž můžeme opravdu s nadsázkou označit jako dualitu v jednotě, resp. dočasné společné soužití dvou individuálních lidských životů. Nastane-li pak výjimečná situace, kdy je zdraví či život matky vývojem nenarozeného dítěte prokazatelně vážným způsobem ohrožen, je nutné položit si otázku, který z dotčených lidských životů má být z hlediska poskytované právní ochrany upřednostněn? Dle našeho názoru není správným řešením této situace výkladově degradovat ochranu nenarozeného dítěte na pouhou ústavní hodnotu, resp. odepř́it mu ochranu jeho základních práv. Naopak vnímáme období těhotenství jako právní stav sui generis, kdy se může do kolize dostat právo na život dvou právních subjektů. V takovém excesivním př́ípadě by pak nebylo morálně zdůvodnitelné, aby matka byla i přes dosavadní fyzické a duševní vypětí nucena riskovat prímé ohrožení svého života či zdraví. ${ }^{26}$ Tuto argumentaci však nelze analogicky použít ve vztahu k řešení jiných problémů sociálního charakteru nebo ospravedlnění realizace lidské touhy po novém poznání.

Nutná tedy není změna ústavněprávní ochrany nenarozeného dítěte, ale její odlišná interpretace. S tím související novelizace zákonných předpisů by se pak měla týkat také adekvátní trestněprávní ochrany nenarozeného dítěte před jeho matkou, a to při současném uplatnění privilegovaných skutkových podstat trestných činů. ${ }^{27}$ Tímto způsobem by pak nebylo dotčeno právo ženy na rozhodnutí, zda bude matkou, popř. kolik bude mít dětí. V současné době k tomu lze využít dostupných antikoncepčních prostředků, které mohou efektivně zabránit nechtěnému těhotenství, a to zejména při jejich kumula-

25 Přestože se pro účely našeho výkladu nejedná o stěžejní informaci, je vhodně doplnit, že dle právního názoru daného soudu mohou být lhůty k provedení interrupce regulovány toliko zákonem, nikoli jen podzákonnými právními předpisy.

26 Ze statistického hlediska jsou však interrupce realizovány převážně z důvodů sociálního či ekonomického charakteru. Ty by však měly být státem řešeny komplexně, a to primárně zefektivněním stávajícího systému sociálního zabezpečení, který by vytvořil také sociálně slabším ženám objektivní podmínky pro donošení a následnou výchovu jejich dítěte.

$27 \mathrm{~K}$ tomu srovnej současnou právní úpravu privilegované skutkové podstaty vraždy novorozeného dítěte matkou ve smyslu \ 142 zákona č. 40/2009 Sb., trestní zákoník, ve znění pozdějších předpisů. 
tivní aplikaci. ${ }^{28}$ Pokud je však tento způsob prevence ze strany rodičů zanedbán, vzniká jim dle našeho názoru k takto počatému dítěti přinejmenším morální povinnost respektovat jeho právo na život, které by mělo být chráněno rovněž zákonem. ${ }^{29}$

V souladu s touto koncepcí pak lze počatému dítěti přiznat i další základní práva, která jsou od práva na život kvalitativně odvozena. Z praktického hlediska se bude jednat zejména o vlastnické právo, a to v duchu právní úpravy obsažené v \ 25 zákona č. 89/2012 Sb., občanský zákoník, který uvádí: „Na počaté ditě se bledí jako na již narozené, pokud to vyhovuje jeho zájmuim. Má se za to, že se dítě narodilo živé. Nenarodíli se však živé, hledí se na nè, jako by nikedy nebylo. "Komentářová literatura v tomto kontextu spojuje významnost daného ustanovení zejména s problematikou dědického řízení, v rámci kterého může nenarozené dítě nabývat vlastnických práv. ${ }^{30}$ Jejich soudní ochrana by pak však byla realizovatelná toliko prostřednictvím zákonného zástupce, kterým jsou dle platné a účinné právní úpravy rodiče dítěte. ${ }^{31}$ Eventuálně lze při střetu zájmů uvažovat o analogickém použití institutu zastupování dítěte opatrovníkem, tedy standardně orgánem sociálně-právní ochrany dětí. ${ }^{32}$

\section{Závěr}

Cílem tohoto článku bylo zabývat se otázkami souvisejícími s právní ochranou nenarozeného dítěte. Za tímto účelem byl nejprve pomocí kritické analýzy stanoven jeho morální status, jakožto lidské osoby mající právo na život a lidskou důstojnost. Uvedené

28 NORDQVIST, Christian. What types of contraception are there? Medical News Today [online]. Last reviewed 31. 5. 2016 [cit. 2. 6. 2016]. Dostupné z: http:/ / www.medicalnewstoday.com/articles/162762.php

29 Velmi diskutovanou je pak v tomto kontextu problematika přerušení těhotenství, které je následkem spáchaného trestného činu znásilnění či incestu. V daném př́padě totiž zcela absentuje možnost svobodné volby ženy, zda bude či nebude matkou. V takovém př́padě však lze dle našeho názoru analogicky uvažovat o subsumpci těchto zcela ojedinělých př́padů pod provedení interrupce ze zdravotních důvodů, když je zcela nepochybně výrazným způsobem zasaženo psychické i fyzické zdraví oběti těchto trestných činů. To pak má pravidelně sekundární dopady také do jejího dalšího osobního (sexuálního) či společenského života. V krajním prrípadě je taková negativní zkušenost způsobilá vyvolat deprese, které mohou vyústit až v sebepoškozování či sebevraždu. Srov. BOYD, Cameron. The impacts of sexual assault on women [online]. Melbourne: Australian Institute of Family Studies, 2011, s. 3-4 [cit. 28. 5. 2016]. ISBN 978-1-921414-70-1. Dostupné z: https://aifs.gov.au/sites/default/files/publication-documents/ rs2.pdf

30 FIALA, Josef a kol. Občanský zqákoník. Komentár. Svazeek I. Praha: Wolters Kluwer, a. s., 2014, s. $133-134$. ISBN 978-80-7478-370-8.

31 Vycházet zde můžeme kromě analogického použití domněnek otcovství zejména z ustálené právní doktríny, dle které je matka vždy jistá (Mater semper certa est). I zde by však bylo vhodné pro futuro uvažovat o jejî aktualizaci, a to v kontextu s prosazujícím se fenoménem v podobě náhradního mateřství. Srov. GROCHOVÁ, Martina. Mater semper certa est? Centrum pro lidská práva a demokratizaci [online]. Publikováno 26. 4. 2015 [cit. 28. 5. 2016]. Dostupné z: http://www.centrumlidskaprava.cz/mater-semper-certa-est

32 VLACHOVÁ, Alena, KOPEČKOVÁ, Andrea. Ochrana procesních práv nezletilých v řízení před soudem. Eprávo.cz [online]. Publikováno 20. 7. 2016 [cit. 28. 5. 2016]. Dostupné z: http://www.epravo.cz/ top/clanky/ochrana-procesnich-prav-nezletilych-v-rizeni-pred-soudem-101418.html 
závěry byly posléze konfrontovány s př́slušnou judikaturou a vnitrostátní legislativou. Ta je v současnosti pojata velmi liberálním způsobem, nebot' poměrně široce umožňuje intencionálně zasahovat do přirozeného vývoje počatého lidského života, čím jej tak z hlediska právní ochrany snižuje na pouhý biologický materiál či součást těla matky. Tím v důsledku neporušuje jen lidská práva nenarozeného dítěte, ale také ústavní požadavek rovnosti všech lidí v důstojnosti a právech.

Ochranu lidského života můžeme považovat za určitou posvátnou či nedotknutelnou hodnotu společnosti, které by měla být poskytována náležitá právní ochrana, a to bez jakékoliv diskriminace. Současně je však nutné zohlednit specifickou povahu vztahu, který vzniká mezi matkou a jejím dítětem v prenatálním období. Preference matčina práva na život ovšem není vystavěna na argumentaci zpochybňující právní status nenarozeného dítěte. Jedná se o zohlednění skutečnosti, že matka poskytuje svému dítěti biologické podmínky vývoje, čímž by však nemělo dojít k ohrožení její existence. To však dle našeho názoru nezpochybňuje skutečnost, že nenarozené dítě je lidskou osobou, která je nositelem základních práv. 